\title{
A nemzeti egészségbiztosítási adatvagyon használata betegségteher-elemzésekhez Magyarországon
}

\author{
Boncz Imre dr. ${ }^{1,2}$ - Kovács L. Gábor dr. ${ }^{3,4}$ \\ ${ }^{1}$ Pécsi Tudományegyetem, Egészségtudományi Kar, Egészségbiztosítási Intézet, Pécs \\ ${ }^{2}$ Pécsi Tudományegyetem, Egészségtudományi Kar, \\ Real World \& Big Data Egészség-gazdaságtani Kutatóközpont, Pécs \\ ${ }^{3}$ Pécsi Tudományegyetem, Általános Orvostudományi Kar, Klinikai Központ, \\ Laboratóriumi Medicina Intézet, Pécs \\ ${ }^{4}$ Pécsi Tudományegyetem, Szentágothai János Kutatóközpont, Pécs
}

\begin{abstract}
Rövidítések
BNO = Betegségek Nemzetközi Osztályozása $;$ EFOP = Emberi Erőforrás Fejlesztési Operatív Program; GBD $=($ Global Burden of Disease Study) globális betegségteher-tanulmány; HBCs = Homogén Betegségcsoportok Rendszere; NEAK = Nemzeti Egészségbiztosítási Alapkezelő; OENO = Orvosi Eljárások Nemzetközi Osztályozása; OEP = Országos Egészségbiztosítási Pénztár
\end{abstract}

A betegségteher-elemzések az elmúlt két évtizedben terjedtek el a tudományos kutatásban és a szakmapolitikai döntéshozatalban. A betegségteher- (angol szinonimák: burden of disease; burden of illness; cost of illness) elemzések kvantitatív módon mutatják be egy kórkép vagy egészségi állapot egészségügyi, szociális és költségviszonyait $[1]$.

A betegségteher-elemzések koncepcióját és módszertani alapjait az 1990-es években az Egészségügyi Világszervezet, a Világbank és a Harvard Egyetem kutatócsoportjai fektették le [2]. A 'Global Burden of Disease Study' (GBD) mára átfogó kutatási program lett, amely 145 ország mintegy 3600 kutatóját fogja össze az Institute of Health Metrics and Evaluation keretében a Washingtoni Egyetemen, Christopher J. L. Murray vezetésével $[3,4]$. A betegségteher-vizsgálatokban epidemiológiai mutatókat (betegség-előfordulási gyakoriság, morbiditás, incidencia, prevalencia, mortalitás stb.) és egészségügyi kiadásokat (egészségbiztosítási kiadások: kórház, ambulancia, gyógyszer, alapellátás stb.; táppénzes kiadások; rokkantsági adatok stb.) szokás vizsgálni. A legutóbbi, 2019. évi kutatási eredmények (Global Burden of Disease Study 2019) publikálására a Lancet különszámot jelentetett meg 2020. október 17-én [5].
A betegségteher-elemzések tárgyát a rendelkezésre álló adatforrások jelentős mértékben befolyásolják. A fentebb említett nagy nemzetközi összehasonlító elemzések országos makroszintû adatokat használnak, amenynyiben elérhetók ilyen primer adatok. Egyben ez is a Global Burden of Disease elemzések legnagyobb korlátja: a primer adatok rendelkezésre állása. A nem elérhető elsődleges adatok esetében a meglévő adatok predikciója vagy modellezés révén pótolják a hiányzó adatokat. Ha elérhetők is az adatok, a sokféle definíció, mérési, illetve számolási metódus miatt fokozott figyelmet érdemelnek a nemzetközi összehasonlítások [6].

A rutinszerúen gyújtött, adminisztratív adatbázisokon alapuló elemzéseknek egyre nagyobb szerepük van a tudományos szakirodalomban. Ilyen jellegú elemzéseket számos országból rendszeresen publikálnak: Egyesült Államok [7, 8], Németország [9, 10], Franciaország [11, 12], Japán [13, 14], Belgium [15], Görögország [16]. Újabban pedig már több országot lefedő nemzetközi összehasonlító kutatásokra is használják az adminisztratív egészségügyi adatbázisokat [17].

Az Orvosi Hetilap jelen különszámában magyarországi egészségbiztosítási adatok alapján végeztünk betegségteher-vizsgálatokat. A kiválasztott betegségek, kórképek elsősorban a Pécsi Tudományegyetem konzorciumi vezetésével zajló „EFOP-3.6.2-16-2017-00009: Klinikai kutatások tematikus hálózatának kialakítása és nemzetköziesítése" pályázat keretében folyó klinikai kutatásokhoz kapcsolódnak, illetve népegészségügyi jelentőséggel bírnak. Így bemutatásra kerül az akut szívinfarktus, a vastagbél- és méhnyakdaganatok, a rheumatoid arthritis, a diabeteses polyneuropathia, a pertrochanter törések, a térd- és lábszársérülések betegségterhe. A betegségteher-vizsgálatok tágabb értelmezésben a társa- 
dalmi költségeket is tartalmazhatják (direkt magánegészségügyi kiadásokat, indirekt egészségügyi kiadásokat, egyéb társadalmi költségeket), nem csak a közvetlen közfinanszírozású ellátási költségeket. Elemzéseinkben az egészségbiztosítási rendszer által finanszírozott közvetlen egészségügyi kiadásokra fókuszálunk, mivel a többi potenciális költségelemre nem rendelkezünk adatbázissal.

Adatforrásként általában a Nemzeti Egészségbiztosítási Alapkezelö (NEAK) nemzetközi viszonylatban is egyedülálló finanszírozási adatbázisát használtuk (korábban, 1993 és 2016 között az Országos Egészségbiztosítási Pénztár [OEP] múködtette). Magyarországon 1993-ban vezették be az egészségügyi ellátórendszerben a teljesítményhez kapcsolódó elszámolási és finanszírozási rendszert. A járóbeteg-szakellátásban bevezetésre került az Orvosi Eljárások Nemzetközi Osztályozásán (OENO) alapuló tevékenységi lista, amely valamennyi, a járóbeteg-szakellátásban használható orvosi-egészségügyi tevékenységhez egy-egy kódot és tevékenységleírást tartalmaz. Ezen több ezer kód lefedi a teljes járóbetegellátási - beleértve a szakrendelőket, ambulanciákat tevékenységet, továbbá a képalkotó és laboratóriumi diagnosztika során végzett tevékenységeket. Az aktívfekvőbeteg-szakellátásban a Homogén Betegségcsoportok Rendszerét (HBCs) használjuk hazánkban, szintén 1993 óta. A mintegy 700 betegségcsoport lefedi az aktívfekvőbeteg-szakellátásban ellátott valamennyi betegséget. A beavatkozások tevékenységi kódrendszere folyamatos korszerúsítést igényel. Az új, innovatív beavatkozások, mütétes eljárások egy része nem kódolható megfelelően a régi OENO-kódokkal, így az új technológiák esetében a társadalombiztosítási befogadási eljárás során új OENO-kódokat is szükséges kialakítani. Az adatbázis fejlesztésében kiemelt jelentőségünek tartjuk a részletesebb orvosszakmai és erőforrás-felhasználási adatok becsatornázását, regiszter jellegû adatgyưjtési modulok beépítését.

A magyar egészségbiztosítási adatbázis óriási előnye nemzetközi összehasonlításban, hogy valamennyi közfinanszírozott egészségügyi szolgáltató egy nagy, országos kiterjedésű adatbázisba jelenti a való életbeli, rutinszerüen gyújtött egészségügyi adatait, lefedve a teljes magyar lakosságot. Ugyanakkor nem kerülnek bele egyrészt a nem NEAK által finanszírozott közellátások (például védőoltások), másrészt a magánfinanszírozású szolgáltatók adatai sem. A NEAK finanszírozási adatbázisának vannak bizonyos korlátai: a jelentési rendszer és a finanszírozási rendszer torzító ösztönző hatásai következtében szisztematikus hibák, potenciális torzulások fordulhatnak elő. A potenciális torzító elemek mint limitáló tényezők külön figyelmet igényelnek az elemzések során. A magyar egészségbiztosítási adatbázis validitása, az esetleges adattorzítás nem haladja meg a nagy adatbázisok szokásos értékeit [18-23].

A NEAK-adatbázisban 1993 óta a Betegségek Nemzetközi Osztályozása (BNO) 10. revíziója szerinti kódokat használjuk. Megjelent már a $\mathrm{BNO} 11$. revíziója is, célszerú felkészülni ennek alkalmazására, a diagnózisalapú keresések konzekvens megtartásával [24].

Jelen kutatásunk során megvizsgáltuk a betegségek előfordulási gyakoriságát és a hozzájuk tartozó egészségbiztosítási kiadásokat a NEAK finanszírozási adatbázisából. Elemeztük az adatokat ellátási formánként (háziorvosi ellátás, járóbeteg-szakellátás, aktív- és krónikusfekvőbetegszakellátás, gyógyszer-ártámogatás stb.), nemenkénti és korcsoportos bontásban. Az eredményeket az egyes betegségek jellegzetességeihez igazítva mutatjuk be.

1. táblázat |A vizsgált kórképek okozta egészségbiztosítási betegségteher elemzésének összefoglalása

\begin{tabular}{|c|c|c|c|c|c|c|c|c|c|}
\hline \multicolumn{2}{|l|}{ Indikátor } & $\begin{array}{c}\text { Heveny } \\
\text { szívinfarktus } \\
\text { (I21) }\end{array}$ & $\begin{array}{c}\text { Vastagbél- } \\
\text { daganat } \\
\text { (C18) }\end{array}$ & $\begin{array}{l}\text { Végbél- } \\
\text { daganat } \\
(\mathrm{C} 20)\end{array}$ & $\begin{array}{l}\text { Méhnyakrák } \\
\text { (C53) }\end{array}$ & $\begin{array}{c}\text { Rheumatoid } \\
\text { arthritis } \\
\text { (M0690) }\end{array}$ & $\begin{array}{l}\text { Diabeteses } \\
\text { polyneuro- } \\
\text { pathia } \\
(\mathrm{G} 6320)\end{array}$ & $\begin{array}{c}\text { Pertrochanter } \\
\text { törés } \\
(\mathrm{S} 7210)\end{array}$ & $\begin{array}{c}\text { Térd- és } \\
\text { lábszársérülés } \\
\text { (S80-S89) }\end{array}$ \\
\hline \multirow{3}{*}{$\begin{array}{l}\text { Prevalencia } \\
\text { per } 100000 \\
\text { fó }\end{array}$} & Férfi & 208,54 & 88,7 & 68,3 & - & 150,2 & 862 & 51,1 & 211,2 \\
\hline & Nő & 129,61 & 69,0 & 35,4 & 25,6 & 464 & 981 & 114,7 & 167,0 \\
\hline & Együtt & 167,3 & 78,5 & 51,1 & - & 314,1 & 924 & 84,3 & 188,1 \\
\hline \multicolumn{2}{|c|}{$\begin{array}{l}\text { A férfi/nő prevalencia } \\
\text { aránya }\end{array}$} & 1,61 & 1,29 & 1,93 & - & 0,32 & 0,88 & 0,45 & 1,26 \\
\hline \multirow{3}{*}{$\begin{array}{l}\text { Összes } \\
\text { NEAK- } \\
\text { kiadás } \\
\text { (milliárd Ft) }\end{array}$} & Férfi & 10,46 & 5,00 & 5,07 & - & 0,32 & 3,00 & 2,05 & 4,58 \\
\hline & No" & 6,26 & 4,44 & 2,82 & 1,28 & 1,32 & 3,63 & 5,28 & 4,23 \\
\hline & Együtt & 16,73 & 9,44 & 7,89 & 1,28 & 1,64 & 6,63 & 7,33 & 8,81 \\
\hline \multirow{3}{*}{$\begin{array}{l}\text { A NEAK- } \\
\text { kiadás } \\
\text { aránya }\end{array}$} & Férfi & $62,6 \%$ & $53,0 \%$ & $64,3 \%$ & $0,0 \%$ & $19,3 \%$ & $45,2 \%$ & $28,0 \%$ & $52,0 \%$ \\
\hline & Nő & $37,4 \%$ & $47,0 \%$ & $35,7 \%$ & $100,0 \%$ & $80,7 \%$ & $54,8 \%$ & $72,0 \%$ & $48,0 \%$ \\
\hline & Együtt & $100 \%$ & $100 \%$ & $100 \%$ & $100 \%$ & $100 \%$ & $100 \%$ & $100 \%$ & $100 \%$ \\
\hline
\end{tabular}

NEAK = Nemzeti Egészségbiztosítási Alapkezelő 
Az 1. táblázat szemlélteti a vizsgált kórképek okozta egészségbiztosítási betegségteher elemzésének összefoglalását. Az egészségügyi igénybevételi adatok alapján számított, 100000 lakosra vetített prevalencia jelentős eltéréseket mutat a nemek között. Egyes kórképek előfordulási gyakorisága jóval magasabb a férfiak esetében: vastagbéldaganat (93\%-kal), heveny szívinfarktus (61\%-kal), míg más kórképeknél a női prevalencia a jelentősen magasabb: pertrochanter törés (2,2-szer), rheumatoid arthritis (3,1-szer). Ennek megfelelően az egészségbiztosítási kiadások is jelentős, nemek közötti eltérést mutatnak. A heveny szívinfarktus $(62,6 \%)$ és a végbéldaganatok $(64,3 \%)$ esetében a kiadások közel kétharmada a férfiaknál jelenik meg. A pertrochanter törés $(72,0 \%)$ és a rheumatoid arthritis $(80,7 \%)$ esetén pedig az egészségbiztosítási költségek meghatározó része nőknél tapasztalható. Külön érdekesség, hogy a pertrochanter törések esetében a férfiak és nők kezelésére fordított összes egészségbiztosítási kiadás több mint fele $(52,4 \%)$ egyetlen korosztálynál, a 70 év feletti nők esetében jelenik meg.

Az országos lefedettségű egészségbiztosítási adatállomány használatával készült betegségteher-elemzések bemutatják az egyes betegségekhez kapcsolódó egészségügyi igénybevételi, előfordulási gyakorisági adatokat. Tájékoztatást adnak az egyes kórképekre fordított egészségbiztosítási kiadások ellátási formánkénti, nemenkénti és korcsoportos arányairól. Ezen elemzések segíthetnek a betegkör azonosításában, az ellátási folyamat fókuszálásában, a forrásallokáció javításában, a demográfiai változásokhoz kapcsolódó ellátási stratégia megtervezésében.

A NEAK-adatbázis a betegségteher-vizsgálatokon túlmenően számos egyéb elemzési lehetőségre alkalmas: elvégezhető az egyes gyógyító eljárások (mütétek, gyógyszeres terápiák) hatékonyságának és eredményességének elemzése, az ellátások minőségének értékelése minőségi indikátorok segítségével, intézményen belüli és intézmények közötti betegutak elemzése, 'input' adatokat szolgáltat egészség-gazdaságtani elemzésekhez.

Anyagi támogatás: A kézirat az „EFOP-3.6.2-16-201700009: Klinikai kutatások tematikus hálózatának kialakítása és nemzetköziesítése” projekt keretében az „Egészségbiztosítási és klinikai real-world adatvagyon hasznosítása” alprojekt támogatásával készült.

Szerzôi munkamegosztás: Koncepció: B. I., K. L. G. Irodalomkutatás: B. I., K. L.G. A kézirat megszövegezése: B. I., K. L. G. A cikk végleges változatát mindkét szerző elolvasta és jóváhagyta.

Érdekeltségek: A szerzőknek nincsenek érdekeltségeik.

\section{Köszönetnyilvánítás}

Köszönjük a Nemzeti Egészségbiztosítási Alapkezelő támogatását az egészségbiztosítási adatok rendelkezésre bocsátásáért.

\section{Irodalom}

[1] Hessel F. Burden of disease. In: Kirch W. (ed.) Encyclopedia of public health. Springer, Dordrecht, 2008. Available from: https://doi.org/10.1007/978-1-4020-5614-7_297 [accessed: January 2, 2021].

[2] Murray CJ, Lopez AD. The global burden of disease. A comprehensive assessment of mortality and disability from diseases, injuries, and risk factors in 1990 and projected to 2020. Harvard University Press, Boston, 1996.

[3] GBD 2017 Causes of Death Collaborators; Roth GA, Abate D, Abate $\mathrm{KH}$, et al. Global, regional, and national age-sex-specific mortality for 282 causes of death in 195 countries and territories, 1980-2017: a systematic analysis for the Global Burden of Disease Study 2017. Lancet 2018; 392: 1736-1788. [Erratum: Lancet 2018; 392: 2170.] [Erratum: Lancet 2019; 393: e44.]

[4] Global Health Estimates 2016: Disease burden by cause, age, sex, by country and by region, 2000-2016. World Health Organization, Geneva, 2018.

[5] Global Burden of Disease Study 2019. Lancet 2020; 396: 11291306.

[6] GBD 2019 Diseases and Injuries Collaborators; Vos T, Lim SS, Afshin A, et al. Global burden of 369 diseases and injuries in 204 countries and territories, 1990-2019: a systematic analysis for the Global Burden of Disease Study 2019. Lancet 2020; 396: 1204-1222.

[7] Eaglehouse YL, Park AB, Georg MW, et al. Consolidation of cancer registry and administrative claims data on cancer diagnosis and treatment in the US Military Health System. JCO Clin Cancer Inform. 2020; 4: 906-917.

[8] Allen AM, Van Houten HK, Sangaralingham LR, et al. Healthcare cost and utilization in nonalcoholic fatty liver disease: realworld data from a large U. S. Claims Database. Hepatology 2018; 68: 2230-2238.

[9] Eyding J, Bartig D, Weber R, et al. Inpatient TIA and stroke care in adult patients in Germany - retrospective analysis of nationwide administrative data sets of 2011 to 2017 . Neurol Res Pract. 2019; $1: 39$.

[10] Langner I, Ohlmeier C, Haug U, et al. Implementation of an algorithm for the identification of breast cancer deaths in German health insurance claims data: a validation study based on a record linkage with administrative mortality data. BMJ Open 2019; 9: e026834.

[11] Tuppin P, Rivière S, Rigault A, et al. Prevalence and economic burden of cardiovascular diseases in France in 2013 according to the national health insurance scheme database. Arch Cardiovasc Dis. 2016; 109: 399-411.

[12] Tuppin P, Rudant J, Constantinou P, et al. Value of a national administrative database to guide public decisions: from the système national d'information interrégimes de l'Assurance Maladie (SNIIRAM) to the système national des données de santé (SNDS) in France. Rev Epidemiol Sante Publique 2017; 65(Suppl 4): S149-S167.

[13] Ohbe H, Matsui H, Fushimi K, et al. Epidemiology of chronic critical illness in Japan: a nationwide inpatient database study. Crit Care Med. 2021; 49: 70-78.

[14] Nishioka Y, Noda T, Okada S, et al. Incidence and seasonality of type 1 diabetes: a population-based 3-year cohort study using the national database in Japan. BMJ Open Diabetes Res Care 2020; 8: e001262.

[15] Ombelet F, Goossens E, Willems R, et al. Creating the BELgian COngenital heart disease database combining administrative and clinical data (BELCODAC): rationale, design and methodology. Int J Cardiol. 2020; 316: 72-78.

[16] Bakirtzis C, Grigoriadou E, Boziki MK, et al. The administrative prevalence of multiple sclerosis in Greece on the basis of a nationwide prescription database. Front Neurol. 2020; 11: 1012. 
[17] Banks H, Torbica A, Valzania C, et al. Five year trends (20082012) in cardiac implantable electrical device utilization in five European nations: a case study in cross-country comparisons using administrative databases. Europace 2018; 20: 643-653.

[18] Gresz M. The National Health Insurance database of Hungary from the viewpoint of a health insurance physician. [Az Országos Egészségbiztosítási Pénztár adatbázisa az egészségbiztosítási szakorvos szemével.] Orv Hetil. 2012; 153: 1234-1239. [Hungarian]

[19] Gresz M. The paranoia of data collection in Hungary and the health system. [Az adatgyújtés paranoiája Magyarországon és az egészségügy.] Orv Hetil. 2012; 153: 1158-1162. [Hungarian]

[20] Fadgyas-Freyler P. Hungarian health resource allocation from the viewpoint of the English methodology. [A magyar egészségügyi forráselosztás vizsgálata az angliai módszerrel.] Orv Hetil. 2018; 159: 183-191. [Hungarian]

[21] Boncz I, Evetovits T, Dózsa Cs, et al. The Hungarian Care Managing Organization Pilot Program. Value Health Reg Issues $2015 ; 7: 27-33$
[22] Eisingerné Balassa B, Csákvári T, Ágoston I. Health insurance pharmaceutical expenditures in Hungary. [Az egészségbiztosítási gyógyszerkiadások alakulása Magyarországon.] Orv Hetil. 2019; 160(Suppl 1): 49-54. [Hungarian]

[23] Kovács G. Changes in disability, reduced working ability and rehabilitation benefits in Hungary between 1990 and 2015. [A rokkantság, megváltozott munkaképesség, rehabilitációs ellátások változása Magyarországon 1990 és 2015 között.] Orv Hetil. 2019; 160(Suppl 1): 29-36. [Hungarian]

[24] Balkányi L. International Classification of Diseases (ICD), 1lth revision. [Betegségek Nemzetközi Osztályozása, 11. verzió.] IME 2019; 18: 11-12. [Hungarian]

(Boncz Imre dr., Pécs, Vörösmarty u. 3., 7621 e-mail: imre.boncz@etk.pte.hu)

A cikk a Creative Commons Attribution 4.0 International License (https://creativecommons.org/licenses/by/4.0/) feltételei szerint publikált Open Access közlemény, melynek szellemében a cikk bármilyen médiumban szabadon felhasználható, megosztható és újraközölhető, feltéve, hogy az eredeti szerző és a közlés helye, illetve a CC License linkje és az esetlegesen végrehajtott módosítások feltüntetésre kerülnek. (SID_1) 